\title{
Nye sko
}

Når våren kommer, er det deilig for både store og små å legge vekk vinterstøvlene og gå ut i solen med lette sko. Barna har vokst fra fjorårets og må ha nye. Da er det viktig at de er riktig utformet. I Tidsskriftet nr. 14-15/1935 skriver 0. Villoch om dårlige barnesko. Han hevder at plattfot kan forhindres ved bruk av hensiktsmessig skotøy i barneårene (Tidsskr Nor Lægeforen 1935; 55: 833).

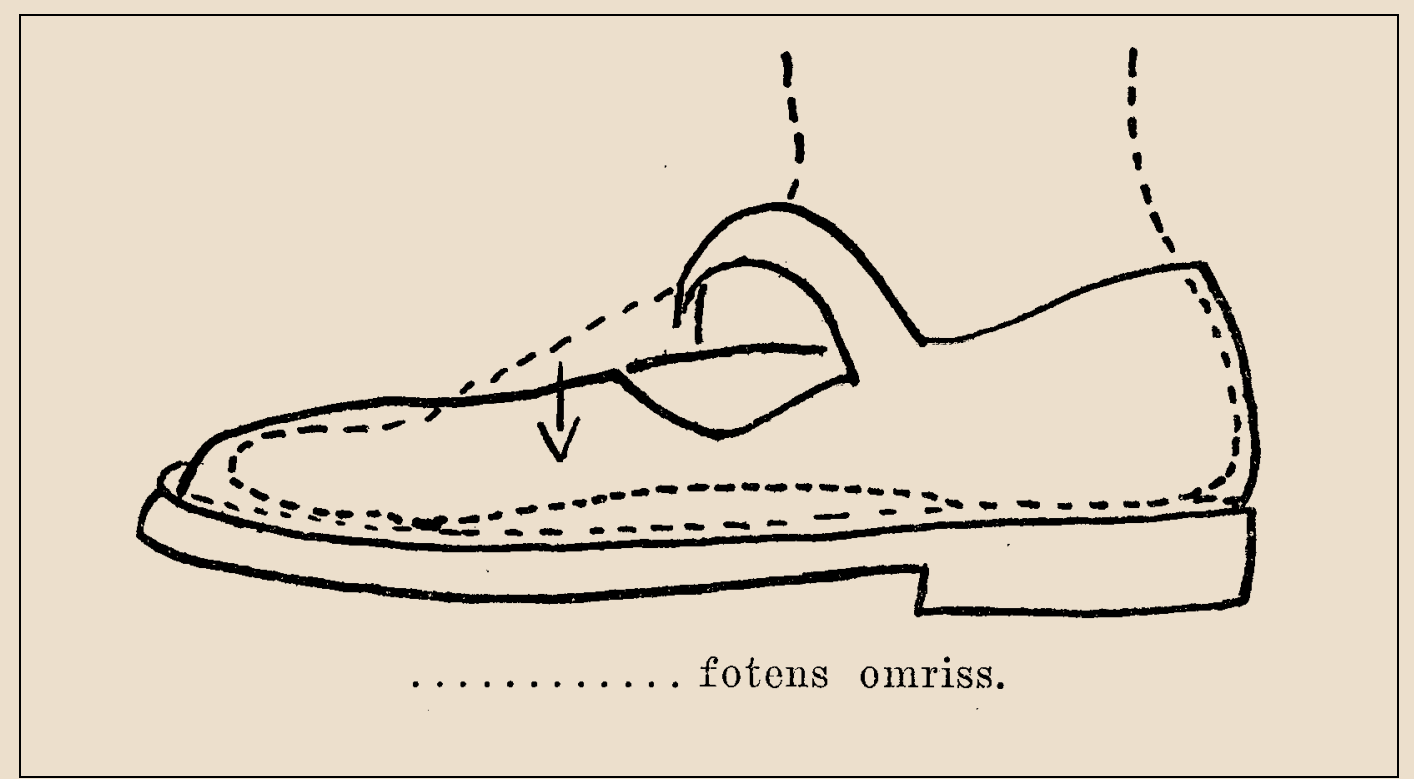

\section{Om fottøi for barn}

Av O. Villoch, Norfold.

Eftersom de grovere hygienske feil (skader) overvinnes, tiltar de mindre viktige relativt i betydning. Jeg vil tillate mig å peke på en sådan, nemlig de barnesko som nu fremstilles. De er nemlig praktisk talt uten undtagelse så lave fortil at fothvelvingen må presses ned for å få foten inn. (Som tegningen forsøker å vise). Da jeg deltok i fysikatkurset 1933 forsøkte jeg ved et besøk på et daghjem å vise dette for Oslo skolelægechef (og barnene der hadde akkurat sådanne sko); men saken syntes ham visst for ubetydelig. Personlig kan jeg vanskelig løsrive mig fra den opfatning at hyppigheten av plattfot må kunne bringes ned ved hensiktsmessig skotøi i barneårene (og ungdomsårene). 